\title{
7.5 Комерційна діяльність роздрібного інтернет-магазину
}

Останнім часом, зручність інтернет-покупок отримала прихильність майже всього світу. Людина може придбати товар онлайн будь-коли та будь-де, зекономивши свій час. Все більшого значення набуває комерційна діяльність, яка спрямована на здійснення купівлі-продажу товарів, та $\epsilon$ неодмінною умовою ефективної діяльності та розвитку інтернет-магазину.

Цілями даної статті є дослідження поняття «комерційна діяльність» та визначення важливості даного показника для роздрібної онлайн-торгівлі.

На сьогоднішній день переваг інтернет-торгівлі стає все більше і більше, а отже популярність покупок онлайн досить стрімко зростає. Через раптовий наплив замовлень, можливий варіант занепаду цієї сфери. На допомогу досвідченим фахівцям та виробникам приходить розумне ведення комерційної діяльності, яка зможе внести чималий розвиток у бізнес.

Комерційна діяльність - це сукупність елементів торгівельної діяльності, що направлена на отримання доходів [335].

Комерційна діяльність представляє собою сукупність послідовно виконуємих торгово-організаційних операцій, які здійснюються в процесі купівлі-продажу товарів та надання торгових послуг 3 метою одержання прибутку [336].

Для того, щоб акт купівлі-продажу пройшов успішно, торговому підприємцю потрібно провести низку оперативно-організаційних та господарських операцій, враховуючи попит населення і ринку збуту товарів, перебування покупців та постачальників продукції, налагодження 3 ними надійних відносин та господарських зв'язків, рекламно-інформаційну роботу зі збуту товарів та їхнє транспортування, організацію торгового обслуговування тощо.

Комерційною діяльністю можна визнати всі покупки товарів, що здійснюються або з метою їх подальшого продажу в тому ж вигляді або після їх 
обробки і доведення до необхідних властивостей, кондицій, якості, або навіть просто з метою здачі їх в оренду, напрокат.

В якості суб'єктів комерційної діяльності виступають і юридичні, і фізичні особи, що наділені правом іiі здійснення. Об'єктами комерційної діяльності на споживчому ринку є товари та послуги.

Основними принципами комерційної діяльності є:

- дотримання чинного законодавства;

• висока культура обслуговування покупців;

• оптимальність комерційних рішень;

• дохідність, прибутковість.

Комерційна діяльність повинна забезпечити виконання важливої функції торгівлі - товарно-грошового обігу. Для налагодження грошово-торгового обміну необхідно використовувати величезний перелік таких комерційних засобів та методів, як оптимізація цін, стимулювання збуту, прискорення оборотності коштів, диверсифікація діяльності в торгівельній сфері.

Комерційна діяльність полягає у дотриманні та виконанні низки завдань (рис. 7.5.1).

Комерційні служби підприємств повинні формувати свої зв'язки 3 партнерами на взаємовигідній основі, тобто, залучаючи до товарообігу продукцію виробників та інших постачальників різних форм власності, а також громадян, які займаються індивідуальною трудовою діяльністю, закордонних постачальників, задля розширення цільової аудиторії.

Цілі комерційної діяльності визначають її основний зміст:

• встановлення партнерських та господарських відносин із суб'єктами ринку;

- аналіз та вивчення джерел закупівлі товарів; 


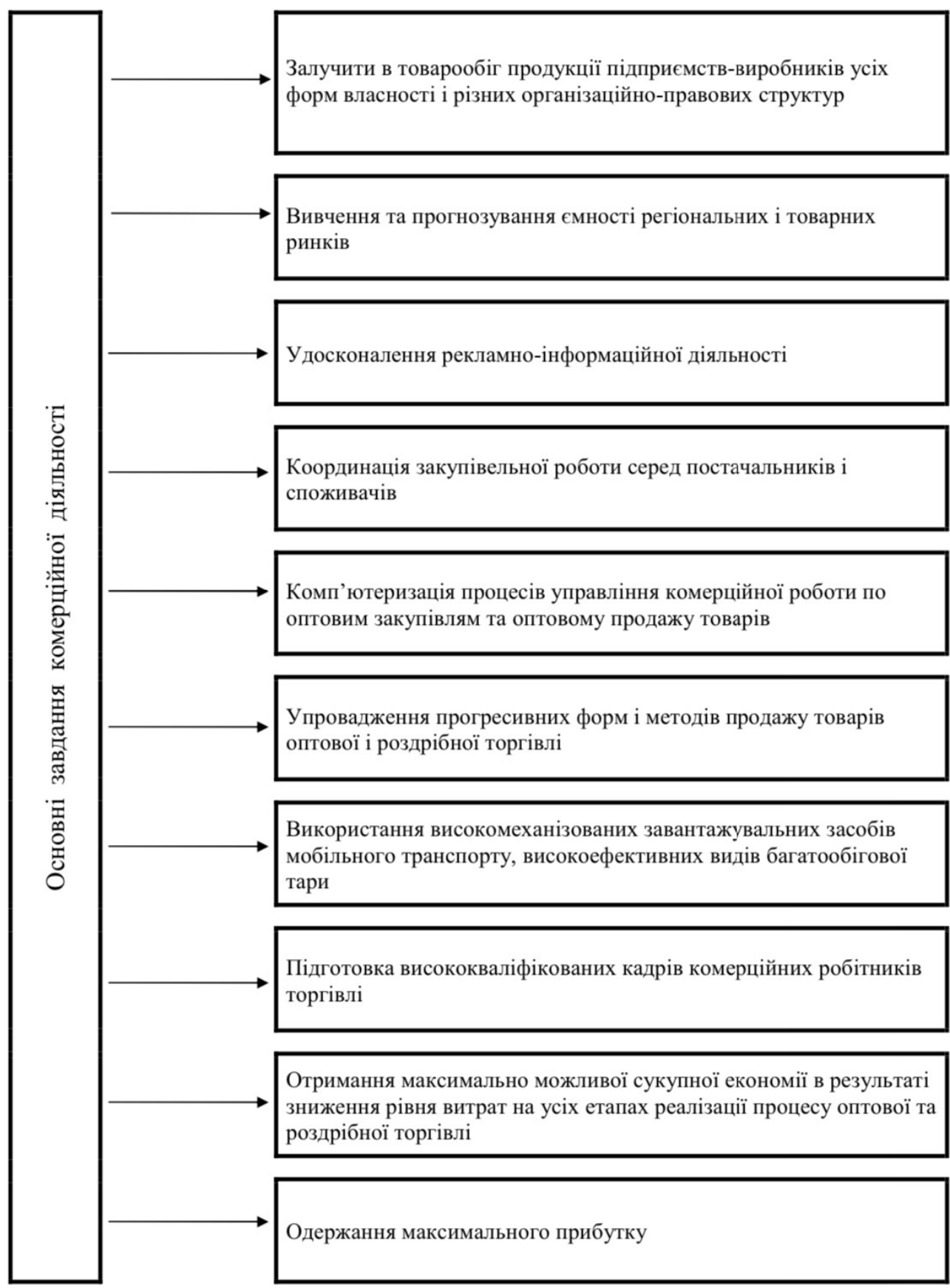

Рис. 7.5.1. Основні завдання комерційної діяльності

• узгодження зв'язку виробництва зі споживанням товарів, орієнтованих на попит покупців (обсяг і обгрунтування своєї продукції, асортимент);

• здійснення купівлі-продажу товарів з урахуванням ринкового середовища;

• розширення існуючих і перспективний розвиток цільових ринків збуту товарів;

• скорочення витрат обігу товарів. 
Діяльність роздрібного торговельного підприємства пов'язана з реалізацією продукції кінцевому споживачеві, що є останнім етапом її просування зі сфери виробництва. Предметом роздрібної торгівлі $\epsilon$ як продаж товарів, так i торговельне обслуговування та надання додаткових послуг клієнтам. Для покупців торговельне обслуговування визначається зручністю та мінімальними витратами часу на здійснення покупки та іміджем підприємства. Надані послуги супроводжуються покупкою продукції і, крім того, післяпродажним сервісним обслуговуванням реалізованих товарів. Отже, процес роздрібної торгівлі складається 3 цілеспрямованої продажу товарів, обслуговування покупців, торгових і післяпродажних послуг.

Функції роздрібної торгівлі визначаються ii сутністю і полягають у наступному:

• задоволення потреб населення за допомогою різноманітних товарів;

- доведення товарів до покупців шляхом організації просторового їх переміщення та подачі до місць продажу;

- утримання балансу між попитом та пропозицією;

• вплив на виробництво з метою розширення асортименту та збільшення обсягу продажів;

• вдосконалення процесу торгівлі та поліпшення обслуговування споживачів.

У роздрібній торгівлі комерційні операції мають свою специфіку, що в першу чергу стосується операцій, наступних за оптовими закупівлями товарів, управління товарними запасами та управління асортиментом товарів. Свою специфіку мають послуги підприємств роздрібної торгівлі та їхня рекламно-інформаційна діяльність.

Оскільки в роздрібній торговельній мережі завершується процес доведення товарів від виробництва до споживача, то комерційна діяльність, пов'язана 3 роздрібним продажем товарів, є найбільш відповідальною, тому що на цьому етапі доводиться мати справу 3 кінцевим споживачем товару. Тому дуже важливо не тільки запропонувати роздрібному покупцеві широкий вибір 
високоякісних товарів, великий перелік послуг, але і використовувати при цьому сучасні, зручні для покупця методи продажу, прогресивні системи розрахунку за покупки тощо.

Розробка Інтернет-магазину та його використання є поширеним питанням на сьогоднішній день, оскільки мільйони людей щодня, не виходячи 3 дому, купують різні товари в електронних магазинах. У світі, а особливо в Україні, величезними темпами зростає кількість користувачів Інтернету і, як наслідок, кількість «електронних» покупців.

Інтернет зближує покупців, реакція на будь-яку подію виникає практично негайно, а відстані зникають. Інтернет-магазини істотно зменшують витрати виробника, заощадивши на утриманні звичайного магазина, розширюють ринки збуту, так само як і розширює можливість покупця - купувати будь-який товар у будь-який час в будь-якій країні, в будь-якому місті, у будь-який час доби. Це дає інтернет-магазинам перевагу перед звичайними магазинами. Цей момент $є$ істотним під час переходу виробників із «звичайної» торгівлі на «електронну».

Онлайн-магазин (електронний магазин) - це комплекс, який дозволяє продавати товари чи послуги через віртуальну мережу «Інтернет» та автоматизувати управління бізнес-процесами. Інтернет-магазини об'єднують елементи традиційної торгівлі та прямого маркетингу. Основними відмінностями інтернет-магазину від традиційного $\epsilon$ інтерактивність, велика кількість інформації та асортименту продукції і персоналізований підхід до кожного покупця. Найбільшим недоліком електронних магазинів є те, що не можна доторкнутися до товару та оцінити його візуально. Але, даний недолік 3 успіхом компенсується великою кількістю інформації, яку не зможе надати продавець в традиційному магазині.

Основними функціями онлайн-магазину є:

- надання насиченої інформації про представлені товари та послуги;

- прийом та обробка замовлень;

- персоналізація споживачів;

- проведення платежів; 
- збір та аналіз статистичної інформації.

Електронний магазин - це сайт, оснащений онлайн-вітриною, що дозволяє приймати замовлення не тільки по телефону, але і через сайт на електронну пошту.

Інтернет-магазин дозволяє оформляти взаєморозрахунки з покупцями, як за готівку, так і за безготівковим розрахунком з можливістю отримання рахункуфактури і вибором «з ПДВ» або «без ПДВ».

Онлайн-магазин також включає всі функції вирішення корпоративного сайту, що дозволяє в рамках цього рішення об'єднати повноцінний корпоративний сайт з роздрібним або оптовим електронним магазином.

Даний онлайн-магазин підійде для тих споживачів, які планують ефективно почати продавати, швидко і недорого організовувати онлайн-вітрину з функцією замовлення товарів за допомогою інтернету.

До переваг онлайн-покупок можна віднести:

•Економія часу. В інтернеті $\epsilon$ можливість вибрати i порівняти характеристики товарів серед декількох магазинів. Дана процедура займе лічені хвилини, на відміну від походів традиційними магазинами. Покупка потрібного товару через інтернет зекономить такий вельми дорогий час для людства. Інтернет-магазин доступний 24 години в добу, 7 днів на тиждень, 365 днів на рік. Працює без свят і вихідних, черги відсутні. Покупець може у будь-який час відірватися від вибору товару, якщо в даний момент у нього немає часу, i повернутися до вибору навіть через декілька діб (всі дані по вибраних позиціях залишаються в аккаунті користувача). Продовжити вибір можна у вільний час на робочому місці або удома, увечері або вночі.

-Низькі ціни. Більшість товарів у віртуальній мережі, можна придбати за нижчу ціну, аніж у звичайному супермаркеті. Чим це зумовлено? По-перше, в інтернет-магазині немає необхідності орендувати торгову площу, по-друге, відсутні витрати по охороні та змісту торгових залів, немає потреби витрачати гроші на найм та навчання продавців-консультантів, по-третє, не потрібно оплачувати послуги посередників. 
•Безкоштовна доставка в більшості випадків. Після оформлення замовлення і передачі його в службу доставки, кур'єр безкоштовно привозить покупку додому або в офіс, в найкращий час. У покупців інтернет-мережі «не болить голова» 3 приводу отримання замовлення, їх не тяготить думка про важку сумку від магазину до будинку.

- Свобода вибору. У відвідувачів інтернет-магазинів існує повна, нічим не обмежена свобода вибору. Сформована заявка поступає не на склад рядового роздрібного магазину, а на найбільший оптовий склад, де $\epsilon$ величезний вибір товарів. У Інтернет - магазині можна ознайомитися 3 інструкціями по застосуванню і подивитися фотографії товарів, не покидаючи улюбленого крісла перед монітором комп'ютера. Звичайно, не можна ознайомитися 3 товаром «живцем», відчути його руками, але $\epsilon$ можливість сходити в звичайний магазин, подивитися на уподобаний товар, ще раз зважити все «за і проти», й істотно заощадити значну суму грошей при покупці через Інтернет - магазин.

•Психологічний комфорт. Споживачі онлайн-магазинів не штовхаються в натовпі інших покупців, з нетерпінням чекаючи, коли підійде вільний менеджер. Там ніхто не докучає настирливими порадами і не примушує купити непотрібну річ. Відсутній будь-який тиск з боку продавця. Консультації з будь-якого питання, здійснюються через службу online підтримки: «Бажаєте замовити новинку, що ще не поступила на склад магазину? Залиште заявку і вас проінформують про надходження по електронній пошті».

•Зручність оплати. Клієнти можуть вибрати найоптимальніший спосіб оплати вибраного товару: готівкою при доставці кур'єром, поштовий або банківський переказ, оплата кредитною картою або електронними грошима (Webmoney тощо). Вони можуть відмовитися від покупки, не сплачуючи витрати при доставці.

-Анонімність. Про покупки відвідувачів інтернет-магазинів ніхто не дізнається, якщо тільки вони самі не захочуть поділитися цією інформацією. Тільки інтернет-магазин гарантує повну анонімність покупця, адже реєструватися можна під будь-яким ім'ям. 
Недоліки інтернет-магазинів:

•Недосконала система доставки. Покупці вимагають від онлайн-магазинів швидкої та якісної доставки замовлень. Покупцям дуже зручно, коли покупки доставляють за вказаною адресою прямо на будинок або на роботу. Недосконалість системи доставки виражається в:

•не дотриманні терміну доставки товару;

- Часто саме швидкість доставки $є$ визначальним чинником у вирішенні при виборі товару в Інтернет - магазині. Якщо товар потрібний терміново, то вибирається той магазин, який пропонує швидку доставку.

-дорогій доставці товару;

•Оперативність служби доставки багато в чому визначає імідж магазину. Проте, по визнанню співробітників електронних магазинів, доставка товарів $€$ одним із найслабших місць компаній.

- Не дуже зручна система оплати. Виявилось, що споживачі не раз відмовлялися від здійснення покупки по причині незапропонованої онлайнмагазином, зручної для них форми оплати. Найпоширенішою формою оплати $\epsilon$ оплата кур'єрові готівкою. Він же наголошується як найбезпечніший спосіб.

•Найбільш економним способом оплати можна віднести передоплату банківським переказом.

•Складна система замовлення. Складна система замовлення полягає в довгому і заплутаному процесі оформлення покупки. Покупцеві необхідно заповнити довгу i часто не зовсім зрозумілою форму, внаслідок чого витрачається багато часу в Інтернет, який не завжди дешево стоїть.

-Також можна відзначити повільну швидкість завантаження деяких магазинів, що може послужити причиною відходу з магазину.

•Нестабільний асортимент. Відповідно, отримати конкурентну перевагу зможе той магазин, який запропонує користувачам весь необхідний ним асортимент. 
•Крім того, нестабільний асортимент деяких магазинів, тобто коли після вибору товару і оформлення покупки виявлялося, що потрібного товару немає на складі або просто магазин так і не зв'язався з покупцем.

•Необхідність реєстрації. Деякі магазини примушують покупця проходити дуже довгий покроковий процес реєстрації. Це відлякує потенційних покупців здійснювати покупки в даному магазині, особливо коли покупець цінує час, що витрачається ним.

•Проблема віртуальності. Неможливість відчуття і доторку до товару, що купується (на картинці він може виглядати відмінно, але при отриманні може мати зовсім інший вигляд).

•Невиконання вибору замовлення. Можлива вірогідність переплутаного кольору товару, моделі, вигляду тощо.

-Втрата замовлення.

Комерційна робота роздрібної торгівлі здійснюється наступними напрямками:

• формування необхідного асортименту товарів у рамках купівельного попиту населення;

- розвиток закупівельної діяльності;

- організація господарських зв'язків з постачальниками, посередниками;

• здійснення процесу купівлі-продажу товарів, супроводжуваними комерційними угодами, товарно-грошовим обміном;

• забезпечення стійких конкурентних позицій при вирішенні комерційних завдань.

Комерційна діяльність у роздрібній торгівлі повинна розвиватися 3 урахуванням змін, що відбуваються в економіці перехідного періоду. Для досягнення цієї мети може служити цільова програма стратегічного планування комерційної діяльності роздрібного торговельного підприємства. Вона є економічним обгрунтуванням розвитку підприємства на комерційній основі, дозволяє оцінити власні потенційні можливості, містить контрольні показники у вирішенні комерційних задач, забезпечує формування фінансових ресурсів. 
У сучасному світі неможливо досягти позитивних результатів у торгівлі, поки комерційною діяльністю не буде пронизана вся сфера цієї галузі. Особлива роль у комерційній діяльності належить комерційних операцій, пов'язаних 3 обігом і доведенням товарів до споживачів. Для цього потрібні координація та взаємодія магазину 3 суміжними i територіальними комерційними структурами. На додачу, необхідно також враховувати ситуацію в галузі, регіоні і в цілому по країні.

На основі узагальнення позитивного досвіду можна виділити відправні положення у вирішенні комерційних задач торговим підприємством, до яких належать:

•чітко сформульовано основну мету магазину і відповідна область комерційної діяльності;

• освіта обгрунтованої організаційної структури комерційної служби та забезпечення іiї взаємодії з функціональними службами торгового підприємства;

•здійснення комерційних угод, товарно-грошових і товарно-обмінних операцій з купівлі-продажу з урахуванням попиту споживачів;

•пошук і заповнення суміжних та раніше не охоплених цільових ринків товарів;

•інформаційно-комп'ютерне забезпечення, що дозволяє оперативно приймати рішення і керувати комерційними процесами;

•в умовах нестабільності та непередбачуваності кон'юнктури ринку протистояння комерційним ризикам;

•навчання персоналу комерційної служби, спрямоване на вивчення економіки ринку, основ комерції, ведення комерційної справи;

•аналіз і оцінка проведеної комерційної роботи.

Комерційна діяльність - це невід'ємна умова споживчого ринку, сфери комерційного підприємництва, де відбувається обмін грошей на товари і товарів на гроші. Під нею слід розуміти процеси, пов'язані з купівлею і продажем товарів, задоволенням попиту покупців, розвитком цільових ринків товарів, 
мінімізацією витрат обігу та отриманням прибутку. При закупівлі та постачання товарів вивчається ринок, встановлюються господарські зв'язки 3 постачальниками, здійснюються комерційні операції, спрямовані на комерційні угоди, укладання контрактів та товарно-грошовий обмін. Комерційна робота повинна супроводжуватися комерційними діями і рішеннями виходячи з умов конкретної зовнішнього середовища і кон'юнктури ринку. При виконанні комерційних функцій слід грунтуватися на економічних законах ринку, фінансової політики і комерційному праві.

Торгівля, задовольняючи потреби і запити споживачів, є кінцевою ланкою діяльності суб'єктів ринку. Особлива роль належить комерційній діяльності, пов'язаної з виконанням комплексу заходів щодо доведення товарів від виробника до покупця. Основними ії завданнями є: вивчення запитів і потреб у товарах з орієнтацією на купівельну спроможність; визначення асортиментної політики, формування i регулювання процесів постачання, зберігання, підготовки до продажу та реалізації товарів в ув'язці 3 цілями діяльності підприємства, забезпечення заданого товарообігу матеріальними і трудовими ресурсами.

Отже, основними цілями комерційної роботи в роздрібній галузі, полягають у забезпеченні доведення товарів до покупців i торговому обслуговуванні 3 урахуванням вимог ринку. Цьому сприяють нові умови господарювання підприємств роздрібної торгівлі. Комерційної діяльності повинен бути притаманний динамізм, обумовлений змінами у зовнішному та внутрішному середовищі, ресурсний потенціал, технології торгівлі, фінансовий стан, що є основою функціонування роздрібної торгівлі. 